\title{
Influence of operating parameters of a settling- based perfusion process on expansion of VERO cells attached on microcarriers
}

\author{
Amal El Wajgali', Frantz Fournier', Eric Olmos', Cécile Gény², Hervé Pinton², Annie Marc ${ }^{*}$ \\ From 22nd European Society for Animal Cell Technology (ESACT) Meeting on Cell Based Technologies \\ Vienna, Austria. 15-18 May 2011
}

\section{Background}

The growing demand for biologicals produced by animal cells motivates the development of more efficient and reliable culture production processes. In the particular case of the industrial production of viral vaccines by Vero cells adhered on microcarriers, the cell propagation phases are mainly devoted to reach high cell density in less time while maintaining a good cell physiological state. Several papers have reported the optimization of culture conditions for microcarrier cultures [1-4]. Otherwise, perfusion bioreactors, based on continuous medium renewal and cell retention, can be a good alternative to batch systems. Among the various technologies for cell retention, gravitational settler is a promising device for large-scale perfusion culture process. This simple device takes advantage of the difference between the cell settling rate and the medium harvesting flow rate. Moreover, in the particular case of cells attached on microcarriers, it is more suitable than in the case of single suspended cells. So, the aim of this work was to evaluate the performances of adherent Vero cell cultures performed inside a perfused bioreactor using a gravitational settler as cell retention device. The study focused on the influence of two operating parameters, such as microcarrier concentration (MCs) and initial cell density $\left(C_{0}\right)$, on the cell growth.

\section{Materials and methods}

Vero cells were provided by Sanofi Pasteur and cultivated in a serum-free medium attached on Cytodex-1 microcarriers (GE Healthcare). Cultures were performed

\footnotetext{
* Correspondence: annie.marc@ensic.inpl-nancy.fr

'Laboratoire Réactions et Génie des Procédés, UPR-CNRS 3349, Vandoeuvrelès-Nancy, France

Full list of author information is available at the end of the article
}

in a $2 \mathrm{~L}$ bioreactor (Pierre Guérin, France) controlled at $\mathrm{pH}: 7.2$, temperature: $37^{\circ} \mathrm{C}, \mathrm{pO}_{2}: 25 \%$ with an agitation rate of $90 \mathrm{rpm}$. After $48 \mathrm{~h}$ of batch culture, the perfusion medium flow rate was started at $0.5 \mathrm{vol} . \mathrm{d}^{-1}$. The harvest flow rate was made through a settling glass tube. The concentration of adherent cells was measured by the crystal violet method.

A Design of Experiment (DoE) was set up, with the objective to study the effect of two operating parameters (MCs and $\mathrm{C}_{0}$ ) in order to reach high maximal cell density and rapid cell growth. The chosen criteria for DoE response were the maximal cell concentration, either per medium volume (cells. $\mathrm{mL}^{-1}$ ) or per microcarrier (cells.MCs ${ }^{-1}$ ), and the population doubling level (PDL). A D-optimal design was chosen because of the irregularity of the experimental region. Three levels were defined for each parameter. The Modde 7 software was used to generate the DoE: 7 experiments plus one repetition in order to assess the repeatability. Theoretical initial cell densities $\left(\mathrm{C}_{0}\right)$ were corrected by the experimental values. The table 1 gives the corresponding operating parameters of the various perfused cultures.

\section{Results}

The settling tube used as cell retention device was observed to be not only easy-to-implement but also a reliable system for retention of cells adhered on microcarriers. Indeed, no microcarrier was found in the harvest flow rate, whatever the culture operating conditions. The evolution of cell density was studied for more than 10 days. A final stabilization of the maximal cell density was observed during several days for all experiments (Table 1). The repeatability was evaluated with experiments 7 and 8, performed with the same operating parameters (MCs: 2.5 g.L $\mathrm{L}^{-1}$ and $\mathrm{C}_{0}: 14200$ 
Table 1 Operating conditions and experimental results for perfused experiments.

\begin{tabular}{|c|c|c|c|c|c|}
\hline \multirow[t]{2}{*}{ Experiments } & \multicolumn{2}{|c|}{ Operating factors } & \multicolumn{3}{|c|}{ Experimental results } \\
\hline & MCs $\left(g . L^{-1}\right)$ & $C_{0}\left(\right.$ cells. $\left.\mathrm{cm}^{-2}\right)$ & $C_{\max }\left(10^{6}\right.$ cells $\left.\cdot \mathrm{mL}^{-1}\right)$ & $C_{\max }\left(\right.$ cells.MC $\left.C^{-1}\right)$ & $\mathrm{PDL}$ \\
\hline 1 & 2.5 & 9100 & 1.9 & 114 & 4.2 \\
\hline 2 & 5 & 23000 & 3.9 & 116 & 2.9 \\
\hline 3 & 1.2 & 6000 & 2.5 & 311 & 6.3 \\
\hline 4 & 3.8 & 10100 & 2.7 & 106 & 3.9 \\
\hline 5 & 1.2 & 28500 & 2.2 & 275 & 3.8 \\
\hline 6 & 3.8 & 36000 & 3.2 & 125 & 2.4 \\
\hline 7 & 2.5 & 14200 & 2.5 & 149 & 3.7 \\
\hline 8 (7bis) & 2.5 & 14200 & 2.5 & 147 & 4.2 \\
\hline
\end{tabular}

cells. $\left.\mathrm{cm}^{-2}\right)$. Both experiments displayed similar cell kinetics and reached the same maximal cell density (2.5 x $10^{6}$ cells. $\mathrm{mL}^{-1}$ ).

On the one hand, the experimental kinetics results were compared on the basis of the maximal cell concentrations. The highest cell density per medium volume $\left(3.9 \times 10^{6}\right.$ C. $\left.\mathrm{mL}^{-1}\right)$ was reached for the culture performed with the highest MCs (5 g.L $\mathrm{L}^{-1}$, exp. 2). But the highest cell density per microcarrier (300 cells.MCs ${ }^{-1}$ ) was obtained with the lowest MCs of 1.2 g.L. $\mathrm{L}^{-1}$ (exp. 3 and 5) whatever the $C_{0}$ value (6 000 and 23500 cells. $\mathrm{cm}^{-2}$ ). It was also pointed out that, according to the microcarrier concentration used, the maximal cell density (in cells per medium volume) could depend on the initial cell-to-bead-ratio. Indeed, the two experiments performed with 2.5 g. $\mathrm{L}^{-1} \mathrm{MCs}$ reached $1.9 \times 10^{6}$ cells. $\mathrm{mL}^{-1}$ (exp. 1) when $\mathrm{C}_{0}$ was 9100 cells.cm ${ }^{-2}$, and $2.5 \mathrm{x}$ $10^{6}$ cells.mL ${ }^{-1}$ with $\mathrm{C}_{0}$ of 14200 cells.cm ${ }^{-2}$ (exp. 7). The same conclusion was obtained with 3.8 g.L $\mathrm{L}^{-1}$ MCs (exp. 4 and 6). Therefore, the highest cell concentration was reached when a sufficient number of cells per microcarrier was respected at the beginning of culture. But, with $1.2 \mathrm{~g} . \mathrm{L}^{-1} \mathrm{MCs}$ the maximal cell density was similar for the two $\mathrm{C}_{0}$ used, suggesting that the maximal cell concentration was less dependent on initial cell density at very low carrier concentration.

Furthermore, the statistical analysis of the influence of the operating parameters, on the basis of the three chosen criteria, showed that the best model was observed with the PDL values. The model predicted correctly experimental results and was described by a first-order polynomial. The regression showed satisfactory statistical qualities and neither interaction nor quadratic effects were found significant. The model indicated that low values for both operating factors $\mathrm{MCs}$ and $\mathrm{C}_{0}$ favoured a higher PDL.

\section{Conclusion}

The easy-to-implement settling tube was a reliable system for retention of cells adhered on microcarriers. The influence of two operating parameters (MCs and $\mathrm{C}_{0}$ ) on the Vero cell growth was quantified according to three criteria related to cell growth (cells. $\mathrm{mL}^{-1}$, cells.MCs ${ }^{-1}$ and PDL). While the highest microcarrier concentration led to the highest total amount of attached cells, the lowest MCs induced the best carrier recovery by the cells. Moreover both low MCs and $\mathrm{C}_{0}$ values favored a high PDL. These results provide a preliminary screening of operating conditions before undertaking a rational scale-up of the perfusion process.

\section{Author details}

'Laboratoire Réactions et Génie des Procédés, UPR-CNRS 3349, Vandoeuvrelès-Nancy, France. ${ }^{2}$ Sanofi Pasteur, Marcy L'Etoile, France.

Published: 22 November 2011

\section{References}

1. Clark JM, Hirtenstein MD: Optimizing culture condition for the production of animal cells in microcarrier culture. Ann. N. Y. Acad. Sci 1981, 369-33.

2. Mendonça RZ, Prado JCM, Pereira CA: Attachment, spreading and growth of VERO cells on microcarriers for the optimization of large scale cultures. Bioprocess Eng 1999, 20:565-571.

3. Sean P, Forestell SP, Kalogerakis N, Behie LA, Gerson DF: Development of the optimal inoculation conditions for microcarrier cultures. Biotechnol. Bioeng 2004, 39:305-313.

4. Bock A, Sann H, Schulze-Horsel J, Genzel Y, Reichl U, Möhler L: Growth behaviour of number distributed adherent MDCK cells for optimization in microcarrier cultures. Biotechnol. Progr 2009, 25:1717-1731.

doi:10.1186/1753-6561-5-S8-P60

Cite this article as: El Wajgali et al:: Influence of operating parameters of a settling-based perfusion process on expansion of VERO cells attached on microcarriers. BMC Proceedings 2011 5(Suppl 8):P60.

\section{Submit your next manuscript to BioMed Central} and take full advantage of:

- Convenient online submission

- Thorough peer review

- No space constraints or color figure charges

- Immediate publication on acceptance

- Inclusion in PubMed, CAS, Scopus and Google Scholar

- Research which is freely available for redistribution 